\title{
The Effects of Wintering in Different Climatic Regions of Turkey on Some Physiological Characteristic of Caucasian Honey Bee (Apis mellifera caucasica) Colonies
}

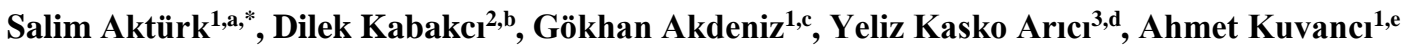 \\ ${ }^{1}$ Apiculture Research Institute, Republic of Turkey Ministry of Agriculture and Forestry, 52000 Ordu, Turkey \\ ${ }^{2}$ Faculty of Applied Sciences, Department of Animal Production and Technologies, Mus Alparslan University, 49250 Mus, Turkey \\ ${ }^{3}$ Faculty of Medicine, Department of Biostatistics and Medical Informatics, Ordu University, 52200 Ordu, Turkey \\ *Corresponding author
}

\section{A R T I C L E I N F O A B S T R A C T}

Research Article

Received : 15/05/2020

Accepted : 05/10/2020

\section{Keywords:}

Physiological characteristics

Location

Overwintering

Microclimate

Brood areas
This study was conducted in two locations have different altitudes in the cities which have different climates as Ankara, Ordu, Erzurum, Mersin. The purpose of this work was to define some physiological properties of the bees such as the survivability of colony, wintering ability, usage of stoked honey and to discuss all these data. This study lasted two years and the second year was the continuation of the first year. At the beginning of the year, colonies which has the same genotype were equalized as number of combs covered with bees, stocked honey and brood areas and so on. According to the data analysis, it was obtained that the quantity of the stocked honey was not statistically significant by the region $\times$ altitude $\times$ year interaction. However, year $\times$ region and region $\times$ altitude interactions were statistically significant. Similarly, it was obtained that the wintering ability was not statistically significant by the region $\times$ altitude $\times$ year interaction. The only year $\times$ region interaction was statistically significant. Also, descriptive statistics obtained for the survivability of the colonies (\%) during the first and second year was added statistically to this application. As a result, this work showed that migratory beekeepers could reevaluate the regions which have the microclimate properties in Aegean, Mediterranean, and the Black Sea. And new research should be made by adding different species of honeybees for the performance of overwintering in different climates. salim.akturk@tarimorman.gov.tr gkhanakdnz@gmail.com e@ahmetkuvanci@hotmail.com

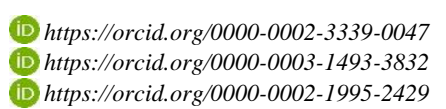

b@dilek_kabakci@hotmail.com
d@yelizkasko@gmail.com iD https://orcid.org/0000-0002-1995-2429

\section{(c) () () () This work is licensed under Creative Commons Attribution 4.0 International License}

\section{Introduction}

Honey bees are poikilothermic creatures. Their body temperatures increase and decrease depending on environmental temperature (Heinrich, 1993; Goodman, 2003; Kaya, 2007). They are particularly affected by temperature, which is an environmental factor. In this sense, they have developed the ability to regulate temperature and similar environmental conditions in the nest (Furgala, 1997). However, when the temperature difference shows an excessive increase or decrease, it requires extra energy production to regulate it and therefore they get exhausted. Comfortable warmth for bees in terms of temperature factor is $26^{\circ} \mathrm{C}$. Any change or deviation that occurs at this level will require extra energy consumption and thus economic loss (Omran, 2011). Considering this situation, the seasonal temperature change is more important for bees by comparison with most species. There are great differences between regions in terms of some other conditions, such as winter season, its duration and temperature. Failure to take adequate measures or wrong choices results in loss of both the colony and the number of individuals in the colony (Yorgancioğlu, 2001; Güler, 2006). The fact that Wintering colonies successfully constitute is one of the most important problems affecting productivity in Turkey where winter losses are quite high.

Temperature increases in recent years have also affected the honey bee colonies. Especially during the wintering period, the temperature rise above 15 degrees during the day leads the winter cluster to expand and leads the honey bees to fly. The sudden drop in temperature on the same day or even in the same hour causes honey bees not to return to their hives. The formation and reopening of clusters caused by the temperature change and the repetition of this situation many times can create problems both in the economic use of food stocks and in the formation of clusters (Güler, 2006; Akdeniz et al., 2014). 
Most of the migratory beekeepers operating in Turkey transfer honey bee colonies in autumn months to various regions that exhibit microclimate characteristics and to Aegean and Mediterranean coastlines where winters are mild, and spring comes early, and where flowering plants and nectar resources can be found in winter (Akyol et al., 2006; Y1ld1z, 2007). Especially in the last 20 years, this temperature increase which is also stated in the records of the General Directorate of Meteorology should lead to further studies to identify suitable wintering regions. In order to make beekeepers economically stronger with the increase in productivity and production depending on successful wintering, to investigate the effects of seasons and altitude on wintering performance and to clarify doubtful approaches among the beekeepers related to the subject; 4 groups were formed in Ankara, Erzurum, Mersin and Ordu provinces where continental climate, harsh continental climate, Mediterranean climate and the Black Sea climate are experienced respectively. These groups were divided into 2 subgroups as "provincial-level" and "high provincial level" considering the altitude factor and the year was repeated. In this study, which was carried out in $4 \times 2 \times 2$ factorial design in a completely randomized design; it is aimed to determine and interpret such physiological features as the colony survivability related to wintering, wintering ability and the consumption of stock honey.

\section{Material and Methods}

The research was conducted in accordance with the work schedule, in the last week of 2015-2016 April in the first year. The material and methods of this study were explained below in order.

\section{Colonies' Supply Equalization Works}

In the last week of April 2015, 90 units of 7-8 frame colonies were procured from the same apiary for the herd for which 80 colonies had been planned to get created. In the second week of July, 0 year- old Caucasian (Apis mellifera caucasica) sister queens were purchased in accordance with the project content, from an operation which has the production permission of the Ministry of Agriculture and Forestry and they got accepted to the colonies. In the period of adoption of queens; strong colonies were divided, existing queens were collected, and colonies were left without queens for 2 days if any, existing queen cells were disrupted, and new queens were tried to get accepted. Due to the low ratio of acceptance which is thought to be caused by seasonal conditions, 56 units of 7-frame colonies with the same genotypes, honey stocks, broods, etc. were created in the first year of the study. In the second year of the study, the procedures carried out in the first year were repeated in accordance with the work calendar, and 80 colonies assumed to be equal were created.

\section{Creating Groups and Shipping}

In the first year, 56 colonies assumed to be equal were numbered and divided into 4 groups in fourteens, and each group was divided into 2 subgroups of 7 . After completing caring, feeding and treatment of varroa destructor mites in the colonies, the meteorological data of the study areas were followed, and colonies were transferred to the specified wintering regions just before the winter conditions started to show effect (October 2nd week). The colonies in the subgroups that form the groups were left in places at two different heights for wintering. In the second year, 80 colonies were divided into 4 groups as 20 colonies, and each group was divided into 2 subgroups and they were left in the same regions by carrying out the same procedures.

\section{Wintering Period}

The colonies were placed in the regions where they got distributed from the 2 nd week of October to the last week of March. The findings got tried to be reached through the physiological characteristics listed below together with explanations within the project. Colony survivability (\%): It was determined by using the number of colony losses during the trial period (Güler, 1999; Yeninar et al., 2010; Cengiz and Erdoğan, 2017). Wintering Ability (\%): The number of combs covered with bees in autumn care of the colonies and the number of combs covered with bees at the end of the winter was determined, and then the calculation was made a number of combs covered with bees coming out to spring/number of combs covered with bees entering winter x 100 (Genç et al., 1999; Arslan et al., 2004; Cengiz and Dülger, 2018). Quantity of The Stocked Honey (kg/colony): Honey consumption per colony during wintering has been determined (Dülger, 1997; Jevtic et al, 2005; Cengiz and Erdogan, 2017).

\section{Experimental Design and Statistical Analysis}

According to the experiment conducted in a $4 \times 2 \times 2$ factorial design in a completely randomized manner, the provincial factor has 4 levels as Ankara, Ordu, Erzurum and Mersin; the altitude factor has 2 levels as the provincial level and the higher provincial level; the year factor has two levels as the first year and second year. In this experiment, which was conducted in 7 replicates in the first year and 10 replicates in the second year, the data obtained in order to investigate the combined effects of the factors were evaluated with three-way ANOVA. Before the ANOVA tests, Levene's test was used to test for homogeneity of group variance The Tukey's HSD was used for post hoc comparisons between means.

\section{Results}

Descriptive statistical values and statistical comparison results of the amount of honey ( $\mathrm{kg} /$ colony) consumed by the colonies during wintering period obtained the first and second years of the study are given in Table 1 .

The amount of stock honey ( $\mathrm{kg} /$ colony) consumed by bees during the wintering in Ankara and Ordu provinces, which was obtained from the experiment repeated for two years at the provincial and altitude level, was evaluated by three-way ANOVA method and the results are given in Table 3.1. The region $\times$ altitude $\times$ year interaction was not statistically significant in terms of the amount of stock honey $(\mathrm{P}>0.05)$, instead, the year $\times$ region and region $\times$ altitude interactions were statistically significant $(\mathrm{P}<0.01)$. The results of the Tukey's post hoc test performed to determine different averages were given in letter notation alongside the averages. When Tukey test results are evaluated, it is seen that stock honey consumed during wintering in Ordu is significantly higher than 
Ankara province in both years $(\mathrm{P}<0.05)$. While there is no difference between years in Ankara $(\mathrm{P}>0.05)$, the amount of stock honey consumed during the wintering in Ordu during the first year was significantly higher than the second year $(\mathrm{P}<0.05)$. While there is no difference between the amount of stock honey consumed by the bees wintered at two level (province and higher level) of Ordu $(\mathrm{P}>0.05)$, in Ankara the amount of stock honey consumed by bees is significantly higher in higher-level compared to the province level $(\mathrm{P}<0.05)$. While there is no difference between Ankara and Ordu in terms of the province level $(\mathrm{P}>0.05)$, the amount of stock honey in higher-level consumed by bees Ordu is higher than Ankara $(\mathrm{P}<0.05)$.
In the first year in Erzurum (higher level) and in the second year in Mersin (higher level), the data obtained from these provinces could not be included in the evaluation by factorial variance analysis due to the death of bees wintered in the regions. One-way ANOVA and Tukey's post hoc test were used to compare the data obtained from these provinces. As a result of the ANOVA, the difference between the averages of the subgroups was found to be statistically significant $(\mathrm{P}<0.001)$. According to the results of the Tukey test to determine the different averages, no significant difference has been found between Erzurum and Mersin provinces in both years $(\mathrm{P}>0.05)$.

Table 1. Descriptive statistical values and statistical comparison results of the amount of honey (kg / colony) consumed by the colonies during the wintering period obtained the first and second years of the study

\begin{tabular}{|c|c|c|c|c|c|c|c|c|c|c|c|c|}
\hline \multirow{2}{*}{ A } & \multicolumn{4}{|c|}{ I. year } & \multicolumn{4}{|c|}{ II. year } & \multicolumn{4}{|c|}{ General } \\
\hline & $\mathrm{n}$ & Mean & Std.E. & Std.D. & $\mathrm{n}$ & Mean & Std.E. & Std.D. & $\mathrm{n}$ & Mean & Std.E. & Std.D. \\
\hline \multicolumn{13}{|c|}{ Ankara } \\
\hline PL & 7 & 10.377KLMNO & 0.215 & 0.568 & 8 & 10.375 KLMNO & 0.347 & 0.980 & 15 & $10.376^{\mathrm{Aa}}$ & 0.203 & 0.78 \\
\hline $\mathrm{H}$ & 7 & $8.440 \mathrm{P}$ & 0.406 & 1.075 & 9 & $9.438 \mathrm{NOP}$ & 0.361 & 1.084 & 16 & $9.001^{\mathrm{Bb}}$ & 0.290 & 1.16 \\
\hline $\mathrm{T}$ & 14 & $9.409 \mathrm{Ba}$ & 0.348 & 1.301 & 17 & $9.879 \mathrm{Ba}$ & 0.270 & 1.114 & & & & \\
\hline \multicolumn{13}{|c|}{ Ordu } \\
\hline PL & 4 & $11.485 \mathrm{KL}$ & 0.229 & 0.458 & 9 & 10.749 KLM & 0.208 & 0.625 & 13 & $10.975^{\mathrm{Aa}}$ & 0.184 & 0.66 \\
\hline $\mathrm{H}$ & 6 & $11.770 \mathrm{~K}$ & 0.157 & 0.385 & 10 & $10.526 \mathrm{KLMN}$ & 0.169 & 0.535 & 16 & $10.993^{\mathrm{Aa}}$ & 0.195 & 0.78 \\
\hline $\mathrm{T}$ & 10 & $11.6560 \mathrm{Aa}$ & 0.132 & 0.417 & 19 & $10.632 \mathrm{Ab}$ & 0.132 & 0.575 & & & & \\
\hline $\mathrm{P}$ & \multicolumn{12}{|c|}{$\begin{array}{c}\text { Year: } 0.248 \text {; Region: } 0.000 \text {; Altitude: } 0.002 \\
\text { Year } \times \text { Region: } 0.001^{* *} ; \text { Year } \times \text { Altitude: } 0.561 \text {; Region } \times \text { Altitude: } 0.001^{* *} \\
\text { Year } \times \text { Region } \times \text { Altitude: } 0.079\end{array}$} \\
\hline & \multicolumn{4}{|c|}{ I. year } & \multicolumn{4}{|c|}{ II. year } & \multicolumn{4}{|c|}{ General } \\
\hline A & $\mathrm{n}$ & Mean & Std.E. & Std.D. & $\mathrm{n}$ & Mean & Std.E. & Std.D. & $\mathrm{n}$ & Mean & Std.E. & Std.D. \\
\hline \multicolumn{13}{|c|}{ Erzurum } \\
\hline PL & 2 & 9.420 LMNOP & 0.620 & 0.877 & 9 & 9.823 LMNOP & 0.333 & 0.880 & & & & \\
\hline $\mathrm{H}$ & 0 & - & - & - & 10 & 9.873 LMNOP & 0.175 & 0.303 & & & & \\
\hline \multicolumn{13}{|c|}{ Mersin } \\
\hline PL & 5 & $8.856 \mathrm{OP}$ & 0.307 & 0.687 & 5 & 9.612 MNOP & 0.327 & 0.731 & & & & \\
\hline $\mathrm{H}$ & 4 & 9.680 LMNOP & 0.267 & 0.535 & - & - & - & - & & & & \\
\hline $\mathrm{P}^{+}$ & \multicolumn{12}{|c|}{$0.000 * * *$} \\
\hline
\end{tabular}

A: Altitude, PL: Provincial level, H: Higher level, T: Total, -: out of trial; p:Three-way ANOVA; p $^{+}$One way ANOVA; $* *:<0.01 ; * * *: 0.001$, The distinction between region averages not contain co-uppercase in the same year is statistically significant $(\mathrm{P}<0.05)$, The distinction between year averages not contain co-lowercase in the same region is statistically significant $(\mathrm{P}<0.05)$, The distinction between altitude averages not contain exponential couppercase in the same region is statistically significant $(\mathrm{P}<0.05)$, The distinction between region averages not contain exponential co-lowercase in the same altitude is statistically significant $(\mathrm{P}<0.05)$, The distinction between averages did not contain co-uppercase $(\mathrm{KLMNOP})$ is statistically significant $(\mathrm{P}<0.05)$

Table 2. Descriptive statistical values and statistical comparison results of wintering ability (\%) of colonies obtained in the first and second year of the study

\begin{tabular}{|c|c|c|c|c|c|c|c|c|c|}
\hline \multirow{2}{*}{ Region } & \multirow{2}{*}{ Altitude } & \multicolumn{4}{|c|}{ I. year } & \multicolumn{4}{|c|}{ II. year } \\
\hline & & $\mathrm{n}$ & Mean & Std.E. & Std.D. & $\mathrm{n}$ & Mean & Std.E. & Std.D. \\
\hline \multirow{3}{*}{ Ankara } & PL & 7 & 32.714MNO & 3.840 & 10.161 & 8 & $48.250 \mathrm{KL}$ & 2.562 & 7.246 \\
\hline & $\mathrm{H}$ & 7 & 39.000LMN & 2.582 & 6.831 & 9 & $47.667 \mathrm{KL}$ & 2.333 & 7.000 \\
\hline & $\mathrm{T}$ & 14 & $35.857 \mathrm{Ab}$ & 2.388 & 8.934 & 17 & $47.941 \mathrm{Ba}$ & 1.673 & 6.896 \\
\hline \multirow{3}{*}{ Ordu } & PL & 4 & 32.500LMNOP & 3.500 & 7.000 & 9 & $58.556 \mathrm{~K}$ & 3.648 & 10.944 \\
\hline & $\mathrm{H}$ & 6 & 40.667LM & 2.333 & 5.715 & 10 & $59.800 \mathrm{~K}$ & 4.068 & 12.865 \\
\hline & $\mathrm{T}$ & 10 & $37.400 \mathrm{Ab}$ & 2.286 & 7.230 & 19 & 59.211Aa & 2.679 & 11.679 \\
\hline \multicolumn{2}{|c|}{$\mathrm{P}$} & \multicolumn{8}{|c|}{$\begin{array}{c}\text { Year: } 0.000 \text {; Region: } 0.019 \text {; Altitude: } 0.132 \\
\text { Year } \times \text { Region: } 0.038^{*} \text {; Year } \times \text { Altitude: } 0.169 \text {; Region } \times \text { Altitude: } 0.709 \\
\text { Year } \times \text { Region } \times \text { Altitude: } 0.996\end{array}$} \\
\hline \multirow{2}{*}{ Erzurum } & PL & 2 & 14.00OPR & 0.000 & 0.000 & 7 & 15.143PR & 2.511 & 6.644 \\
\hline & $\mathrm{H}$ & 0 & - & - & - & 3 & 11.667PR & 2.333 & 4.041 \\
\hline \multirow{2}{*}{ Mersin } & PL & 5 & $12.600 \mathrm{R}$ & 1.400 & 3.130 & 5 & 23.000NOPR & 3.674 & 8.216 \\
\hline & $\mathrm{H}$ & 4 & $10.500 \mathrm{R}$ & 2.021 & 4.041 & 0 & - & - & - \\
\hline \multicolumn{2}{|c|}{$\mathrm{P}^{1}$} & \multicolumn{8}{|c|}{0.00} \\
\hline
\end{tabular}

A: Altitude, PL: Provincial level, H: Higher level, T: Total, -, out of trial; *, statistically significant (P<0.05); ***, statistically significant (one-way ANOVA, $(\mathrm{P}<0.001)$, The distinction between region averages not contain co-uppercase in the same year is statistically significant $(\mathrm{P}<0.05)$, The distinction between year averages not contain co-lowercase in the same region is statistically significant $(\mathrm{P}<0.05)$, The distinction between averages did not contain co-uppercase (KLMNOPR) is statistically significant $(\mathrm{P}<0.05)$. 
The amount of stock honey consumed by bees wintered in the higher level of Ordu is found significantly higher than all the averages of Erzurum and Mersin provinces $(\mathrm{P}<0.05)$.

Descriptive statistical values and statistical comparison results of wintering ability $(\%)$ of colonies obtained in the first and second year of the study are given in Table 2 .

The wintering ability of bees obtained from the provincial level and higher level in two-year trials in Ankara and Ordu provinces (\%) was evaluated by threeway ANOVA and the results are given in Table 2 . The region $\times$ altitude $\times$ year interaction was not statistically significant in terms of wintering ability $(\mathrm{P}>0.05)$, only year $\times$ region interaction was statistically significant $(\mathrm{P}<0.05)$. Accordingly, the results of the Tukey's post hoc test to determine different averages are given in letter notation alongside the averages. It is seen that there is no significant difference between the provinces in the first year $(\mathrm{P}>0.05)$; however, the wintering ability in Ordu in the second year is statistically significantly higher than the bees wintered in Ankara $(\mathrm{P}<0.05)$. When the years are compared in both provinces, it is seen that bees have higher wintering ability in the second year $(\mathrm{P}<0.05)$.

In the first year in Erzurum province and in the second year in Mersin province, the data obtained from these provinces could not be included in the evaluation with factorial variance analysis due to the death of bees wintered in the higher level.

One-way ANOVA and Tukey's post hoc test were used to compare the data obtained from these provinces. As a result of the ANOVA, the difference between the averages of the subgroups was found to be statistically significant $(\mathrm{P}<0.001)$. According to the results of the Tukey test to determine the different averages, no significant difference was found between Erzurum and Mersin provinces in both years $(\mathrm{P}>0.05)$. When Ankara and Ordu provinces are examined for wintering ability especially in the second year, it is seen that these provinces have higher wintering ability than both Erzurum and Mersin provinces $(\mathrm{P}<0.05)$.

Descriptive statistical values of the survivability of the colonies $(\%)$ obtained in the first and second year and statistical comparison results are given in Table 3

Table 3.3 Descriptive statistical values of colony survivability (\%) obtained in the first and second year

\begin{tabular}{l|ccllll}
\hline \multirow{2}{*}{ Region } & \multirow{2}{*}{ Altitude } & \multicolumn{2}{c}{ I. year } & \multicolumn{2}{c}{ II. year } & Weighted \\
\cline { 2 - 6 } Ankara & PL & 7 & 100 & 8 & 80 & 89,30 \\
& $\mathrm{H}$ & 7 & 100 & 9 & 90 & 94,38 \\
\hline \multirow{2}{*}{ Ordu } & $\mathrm{PL}$ & 4 & 57 & 9 & 90 & 79,85 \\
& $\mathrm{H}$ & 6 & 86 & 10 & 100 & 94,75 \\
\hline \multirow{2}{*}{ Mersin } & $\mathrm{PL}$ & 5 & 71 & 5 & 50 & 60,50 \\
& $\mathrm{H}$ & 4 & 57 & 0 & 0 & 57,00 \\
\hline \multirow{2}{*}{ Erzurum } & $\mathrm{PL}$ & 2 & 29 & 7 & 70 & 60,89 \\
& $\mathrm{H}$ & 0 & 0 & 3 & 30 & 30,00 \\
\hline
\end{tabular}

PL: Provincial level, H: Higher level,

\section{Discussion and Conclusion}

This study was conducted in order to make beekeepers economically stronger with increasing productivity and production depending on successful wintering, to investigate the effects of seasons and altitude on wintering performance and to clarify doubtful approaches on the subject; and unlike other similar studies this study enabled to reveal advantages and disadvantages of many locations as it was carried out in four different regions and at two different altitudes. In addition, some suggestions were made by considering the analysis results.

When the statistics of the colony survivability (\%) were examined, it was found out that the weighted averages between the locations of two different altitudes in Ordu and Ankara, especially in Ordu province, constituted an important economic difference of approximately $15 \%$ $(94.75 \%-79.85 \%)$. It was thought that this was due to the negativities caused by the temperature fluctuations seen in the winter season in Ordu province where the Black Sea climate prevails.

It was thought that the difference of $30 \%$ between the two locations in Erzurum province was caused by the low temperatures at the higher level. In a study carried out by Genç and Kaftanoğlu (1993); colony survivability (\%) was found to be $27.3 \%$ in the open wintering area of Erzurum. This result was consistent with the findings of the study. Measurements to be done under closed wintering conditions that were not included in this research will contribute to the studies on the determination of this region wintering performances.

In the second year, all the colonies at the high level of Mersin Province died together with lots of colonies in the same region. A reasonable interpretation could not be made due to these deaths which were detected and recorded (20th February 2017) at the Animal Health Branch of the Beekeeping Research Institute and they thought to be caused by nosema and varroa as a result of the autopsies done. It should be kept in mind that the risk of nosema transmission may be greater in coastlines especially in locations where migratory beekeepers prefer mostly compared to the other regions.

Colony wintering ability (\%); The effect of altitude on wintering ability was not determined. Because of Aggressive seasonal conditions in Erzurum and underdevelopment of Caucasian race used in the study compared to the other races in Mediterranean coastal line wintering ability of Ankara and Ordu, especially second year, was much better than the bees wintered in Erzurum and Mersin both at the provincial level and at the higher level in $(\mathrm{P}<0.05)$. In a study carried out by Güler (1995) reported that Caucasian and Thracian genotypes fell behind the other races in adapting to the conditions of the Mediterranean Region, and this was in line with the result obtained. In the first year in Erzurum province and the second year in Mersin province, the data obtained from these provinces could not be included in the evaluation with factorial variance analysis due to the death of bees wintered in the regions higher than the province level. When the years in Ordu and Ankara provinces were compared, it was seen that bees' wintering ability was higher in the second year $(\mathrm{P}<0.05)$. Thus, in such studies where the season can be considered a factor, the importance of year repetition emerged once again. There is no significant difference between provinces in the first year (P>0.05), but it was observed that wintering ability of Ordu in the second year was significantly higher than the bees wintered in Ankara $(\mathrm{P}<0.05)$. The reason for this may be 
that the earlier start of building up of colony in Ordu compared to Ankara. Although the colonies located in Mersin started their development earlier than the other provinces, it was observed that they could not achieve the desired level due to the weakness of the colony at the beginning of spring. Therefore, it was found out that in order to benefit from the early onset of spring development, the colony size should not be low and the races which have been adapted to the region should be preferred.

Usage of stock honey (kg/colony); colonies extinguished due to lack of nutrients were not observed in the study. Although there was be a statistically significant difference between honey consumption among some regions, it was thought to be economically insignificant considering the number of differences.

The fact that stock honey consumed during wintering in Ordu was significantly higher than Ankara province in both years $(\mathrm{P}<0.05)$ supported the positive linear relationship between temperature and honey consumption. Likewise, the relatively low honey consumption of colonies in higher locations supported this thesis. The fact that there was an insignificant difference between Erzurum and Mersin provinces in both years $(\mathrm{P}>0.05)$, can be due to the access of colonies to nectar sources in Mersin during the wintering period.

\section{Acknowledgement}

This article is based on the findings of the research, which was financially supported by TAGEM, with the project number of TAGEM/HAYSÜD/14/06/01/11.

\section{References}

Akdeniz G, Aktürk S, Kabakçı D, Karataş Ü, Kuvancı A. 2014 Effects of Sudden Temperature Change on Overwintering of Honey bee (Apis mellifera L.) Colonies. 12th Asian Apicultural Association Conference. Program book. page:12. Antalya, Turkey

Akyol E, Yeninar H, Şahinler N, Güler A. 2006. The Effects of Additive Feeding and Feed Additives Before Wintering on Honey Bee Colony Performances, Wintering Abilities and Survival Rates at The East Mediterranean Region. Pakistan Journal of Biological Science. DOI: 10.3923/pjbs. 2006.589.592.

Arslan S, Güler A, Çam HM. 2004. Determination of The Wintering Ability Comb Honey Yield of The Different Honey Bee (Apis mellifera L.) Genotypes in Tokat Region. J. Agric. Fac. Gaziosmanpasa Uni. 21: 85-90. Available from: http://ziraat.gop.edu.tr/fkdergi.asp [Accessed: 19 April 2012].

Cengiz MM, Erdoğan, Y. 2017. Comparison of wintering ability and colony performances of different honeybee (Apis mellifera L.) genotypes in Eastern Anatolian/Turkey conditions. Kafkas Univ Vet Fak Derg, 23(6):865-870. DOI:10.9775/kvfd.2017.17667

Cengiz MM. Dülger, C. 2018. Gezginci ve Sabit Arıcılık İşletmelerinde Kontrollü Şartlarda Yetiştirilen Ana Arılarla Oluşturulan Balarısı (Apis mellifera L.) Kolonilerinin Bazı Fizyolojik Özelliklerinin Belirlenmesi. Atatürk Üniversitesi Vet. Bil. Derg. 13(1): 19-27. DOI: 10.17094/ataunivbd. 309110
Dülger C. 1997. Determination of The Performances of Caucasian, Anatolian and Erzurum Honeybee (Apis mellifera L.) Genotypes in Erzurum Conditions and Their Morphological Characters. PhD Dissertation. A.U. Institute of Science, Department of Animal Husbandry, Erzurum, Turkey.

Furgala B. 1997. Outdoor Wintering Productive Colonies. In: Graham, J.M (Editor). The Hive and The Honey Bee. p.829850. ISBN 13: 9780915698165.

Genç F, Dülger C, Dodoloğlu A, Kutluca S. 1999. Comparison of Some Physiological Characteristics of Caucasian, Middle Anatolian and Erzurum Honeybee (Apis mellifera L.) Genotypes. Turk. J. Vet. Anim. Sci. 23: 645-650.

Genç F, Kaftanoğlu O. 1993. Determination of Optimum Wintering Method of Honey Bee Colonies (Apis mellifera L.) in Erzurum Region. TÜBİTAK VHAG-868, Final Certificate, Erzurum, 1-47, 1993.

Güler A. 2006. Honeybee (Apis mellifera L.) Ondokuz May1s University, Agricultural Faculty School Book, No:55, p5455, 278-280, Samsun.

Güler A. 1999. The Study on Morphological and Physiological Characters Affecting The Productivity of Some Honey Bee (Apis mellifera L.) Genotypes of Turkey. Turkish Journal of Veterinary and Animal Sciences, 23 (2): 393-399.

Güler A. 1995. The Study on Morphological and Physiological Characters Affecting the Productivity of Some Honey Bee (Apis mellifera L.) Genotypes of Turkey. PhD Dissertation, Ç.U. Institute of Science, Department of Animal Husbandry, Adana, Turkey.

Goodman L. 2003. Form and Function in the Honey Bee. Cardiff: IBRA - International Bee Research Association, ISBN-13: 978-0860982432 p: 154-155.

Heinrich B. 1993 The Hot-blooded İnsects: Strategies and Mechanisms of Thermoregulation. Harvard University Press, Cambridge, MA, USA.

Jevtic G, Mladenovic M, Nedic N. 2005. The Influence of the Quantity of Honey Bees and Honey Reserves on Winterıng of Honey Bee Colonies. Biotechnology in Animal Husbandry 21 (5-6), p 315, publisher: Institute for Animal Husbandry Belgrade-Zemun, Belgrade.

Kaya N. 2007. The Effects of Wintering with Empty Supers on Relative Humidity, Temperature and Survivability of the Colony in Beekeeping. MSc Thesis, 76 s, Ankara University Institute of Health Sciences, Ankara, Turkey.

Omran NSB. 2011. Wintering of Honey Bee Colonies by Using a New Technique during Winter Season in Sohag Region, Eypt. Journal of Applied Sciences Research, 7(2): 174-182, Sohag, Eypt.

Yeninar H, Akyol E, Şahinler N. 2010. The Effects of Hive Types (Shield and Sword) on Wintering Ability, Survival Rates and Strength of Honeybee Colonies (A. mellifera L.) in Spring Season. Tropical Animal Health and Production. DOI 10.1007/s11250-009-9438-0.

Yildiz A. 2007. Determinaton of Ability of Wintering and Performance of The Colonies at different Altitude in East Mediterranean Region. MSc Thesis, Sutcu Imam University, Institute of Science, Kahramanmaraş, Turkey.

Yorgancioğlu IYY. 2001. The Effects of Different Hive Forms and Feeding Types on Colony Performance and Productivity during Various Wintering Methods of Honeybees. PhD Dissertation, Ankara University Graduate School of Health Sciences, Ankara, Turkey. 